\title{
A content analysis of pre-college lesson plans on human evolution
}

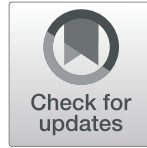

Rebecca L. Hite(1)

\begin{abstract}
One of the most fundamental understandings within biology is evolution, yet often ascribed as one of the most misunderstood scientific concepts by the American public. Despite not being explicitly mentioned in most American science standards, human evolution is nevertheless taught as an engaging context for understanding complex evolutionary processes among pre-college science students. Therefore, pre-college science teachers seek out human evolution content experts (e.g., Smithsonian Institution, NOVA, ENSI) to procure curricula (lesson plans) to teach these concepts in their classrooms. For students to accurately understand human evolution, research recommends lesson plans employ a diversity of direct and indirect evolutionary evidence, infused with social science perspectives related to the nature of science (NOS) and/or socioscientific issues (SSI) to foster necessary conceptual change. Given such empirical affordances of using multiple sources of evidence and integrated social science perspectives to foster conceptual change in teaching human evolution, it is unknown to what extent these attributes are present in lesson plans created by these entities and targeted to pre-college science teachers. To ascertain to what extent pre-college lesson plans on human evolution employ these research-based best practices, this paper analyzed 86 lesson plans created by 18 entities with content expertise in human evolution concepts that had developed online pre-college lesson plans. Among the sampled lesson plans, less than one third (29\%) presented a combination of direct and indirect evidence. Further, a mere 17\% incorporated elements of NOS, where SSI (like historical $(n=3)$ and racial $(n=1)$ ) perspectives were fewer. In sum, findings suggest available resources are deficient in fostering the conceptual change necessary for pre-college students to fully understand human evolution concepts. This study evidences a continued need to ensure best practices are incorporated into human evolution lesson plans created for pre-college teachers.
\end{abstract}

Keywords: Biology education, Conceptual change, Curriculum analysis, Human evolution, Lesson plans, Nature of science, Socioscientific issues, Science education

\section{Introduction}

Evolution is a, if not the, fundamental concept within the biological sciences (Dobzhansky, 2013). Hence, the science education community has openly acknowledged the importance of and advocation for the inclusion of evolution in American pre-college (mainly secondary) science education (American Association for the Advancement of Science, 2006; National Research Council [NRC], 1996; National Science Teaching Association [NSTA], 2013). Yet,

Correspondence: Rebecca.hite@ttu.edu

Department of Curriculum \& Instruction, STEM Education, Texas Tech University, 3002 18th Street, Lubbock, TX 79401-1071, USA a poor (or a lack of) pre-college instruction on evolution has had consequences for students' post-secondary understandings (a precursor to acceptance) of evolution (Brem, Ranney, \& Schindel, 2003; Griffith \& Brem, 2004). According to the Pew Research Center (2013), 60 \% of adults in the United States believe that humans and animals have evolved, compared to $33 \%$ of adults who believe all living things (including humans) have existed in their present form since the beginning of time. Further, among the $60 \%$ of the public polled that affirmed humans and other living things has evolved over time, a quarter of these adults believed that a supreme being had guided that evolution. One understanding derived from this polling is that without

\section{Springer Open}

(c) The Author(s). 2020 Open Access This article is licensed under a Creative Commons Attribution 4.0 International License, which permits use, sharing, adaptation, distribution and reproduction in any medium or format, as long as you give appropriate credit to the original author(s) and the source, provide a link to the Creative Commons licence, and indicate if changes were made. The images or other third party material in this article are included in the article's Creative Commons licence, unless indicated otherwise in a credit line to the material. If material is not included in the article's Creative Commons licence and your intended use is not permitted by statutory regulation or exceeds the permitted use, you will need to obtain permission directly from the copyright holder. To view a copy of this licence, visit http://creativecommons.org/licenses/by/4.0/. 
early understandings of evolution as a biological process, perhaps due to an absence of robust opportunities to learn about evolution (and specifically human evolution), one's religious orientation instead mediates 'understanding' of evolutionary theory as an adult (Brem et al., 2003; Hawley, Short, McCune, Osman, \& Little, 2011). The result has been a general lack of evolutionary understanding, which the National Research Council Committee on A New Biology for the twentyfirst Century (National Research Council [NRC], 2009) has warned will stymie American life and scientific innovation now and for generations to come.

Although research on students' understandings of evolution varies (Biological Sciences Curriculum Study, 2005; Mayr, 1982; McVaugh, Birchfield, Lucero, \& Petrosino, 2011), there is agreement that not (or poorly) teaching evolution makes students susceptible to misconceptions such as the belief in the immutable nature of organisms (Gelman \& Rhodes, 2012), a purposeful selection of traits within nature (Lennox \& Kampourakis, 2013), as well as psychological essentialism and design teleology (Kampourakis, Silveira, \& Strasser, 2016). However, research of a rich teaching of evolution in the pre-college science classroom has shown that students not only develop positive attitudes towards evolution (Lombrozo, Thanukos, \& Weisberg, 2008), but also construct a robust understanding of evolutionary processes (Smith, 2010). This suggests opportunities to learn evolutionary concepts, at the pre-college level, may be indispensable experiences for pre-college students to foster accurate and resilient understandings of evolution (Short \& Hawley, 2015), fostered by (as described in this paper) conceptual change (Posner, Strike, Hewson, \& Gertzog, 1982). These two bodies of research suggest that a simple presentation or exposure to evolution is not enough for pre-college students to foster a rich understanding of evolution. Scholars agree that students, when learning about evolution, should be provided a variety of both direct and indirect evidence for evolution. Direct evidence provides an empirical anchor for students to establish a strong conceptual understanding (Posner et al., 1982) such to generate 'a more detailed understanding of the forces shaping human evolution' (Wilde et al., 2014, p. 4832). Whereas indirect evidence provides students with essential contextual understandings to the complex processes of evolution (National Academy of Sciences, 1999; NRC, 1996; Smithsonian Institution, 2019). Best practice would indicate that it is through a varied combination of evidences to ensure students can engage in robust thinking about evolution (Jensen \& Finley, 1995, 1996). Hence, access to accurate and diverse content-based evolutionary evidence is paramount for teaching human evolution in the precollege science classroom. Also, when teachers learned best practices in teaching against misconceptions, they were more able to establish that evolution's end goal is not to become human (Alters \& Nelson, 2002); aiding them in addressing and resolving students' erroneous ideas that indirect evidence and theory are synonymous with guess work (McVaugh et al., 2011). If best practice is not adhered to, 'students will never be full[y] educated unless they [truly] learn about evolution' (National Center for Science Education, 2019, para 3).

Accurate and diverse evidence is part of quality teaching and learning of human evolution for conceptual change; related research recommends leveraging social science perspectives as best practice to facilitate students' evolutionary understanding while learning evolution concepts (Cobern, 1994; Kampourakis \& McComas, 2010). In this study, the social science perspectives examined are two frameworks with documented success in promoting conceptual change in teaching evolution: The nature of science (NOS) and socioscientific issues (SSI). Therefore, pre-college opportunities that include explicit avenues for students to engage in NOS and SSI would exemplify best practice in fostering conceptual change for robust pre-college teaching of human evolution concepts.

The first framework is termed the NOS, which consists of three conceptual components: knowledge of science, scientific practices, and the nature of science knowledge, the latter defined as "the characteristics of scientific knowledge that are derived from how the knowledge is developed (i.e., scientific inquiry)" (Lederman \& Lederman, 2019, p. 1). Further, the NOS in the context of this study and generally in pre-college science education is intended as a framework to more accurately convey scientific procedures and portray the history scientific endeavor to students (Hodson, 2014; Lederman, 1992; McComas, Clough, \& Almazroa, 1998). Hallmarks of NOS-based instruction make explicit the tentative yet reliable, evolutionary and revolutionary, collaborative as well as refereed nature of scientific knowledge (National Science Teaching Association [NSTA], 2000), affording students improved content knowledge acquisition and facilitating conceptual change when learning about evolution (Abd-El-Khalick \& Akerson, 2004).

The second social science perspective of SSI challenges contextual, social, and historical narratives within science. In SSI, students are tasked to confront ideas or claims that introduces cognitive dissonance with their current knowledge or belief of a topic (Zeidler \& Nichols, 2009). In the United States, evolution is a controversial topic in the public but not scientific sphere, which creates unique challenges in teaching this topic to students in American schools. SSI can have great utility in teaching evolution as it leverages the "moral tension surrounding [controversial topics as] SSI is socioculturally bounded (Zeidler, Herman, 
\& Sadler, 2019, p. 7). And there are ample opportunities for SSI integration given the storied history of human evolution, such as the racial controversy of fossil discoveries in Africa (suggesting the first humans were not from Europe) and its misapplication in the pseudo sciences (Regal, 2004). Hence, SSI can be a shrewd pedagogical strategy for introducing intrigue, infusing ethics, and establishing a sociocultural context of evolution itself as students also wrestle with the complex content of human evolution topics. Further, use of SSI has been found to improve students' understandings of NOS (Abd-El-Khalick, 2003), one of many synergistic effects of SSI pedagogy (see Fowler \& Zeidler, 2016; Sadler, Foulk, \& Friedrichsen, 2017). The converse is also true, of SSI use improves students' understandings of NOS and conceptual change (Bell \& Linn, 2002).

An important aspect to this discussion and to this this study is that the use of the NOS and SSI not only evidences gains for students, but also pre-college teachers. Related studies have found when teachers were provided professional development in the NOS for teaching human evolution, it positively augmented their understanding of evolution (Scharmann \& Harris Jr, 1992) and increased their understanding of the NOS vis-a-vis evolution (Nehm \& Schonfeld, 2007). Similarly, when professionally developed on SSI, science teachers evidence more sophisticated reasoning on SSI-related topics (Owens, Herman, Oertli, Lannin, \& Sadler, 2019). Yet, despite studies extolling the importance leveraging both the NOS (Taber, 2017) and SSI (Sadler, 2011) in pre-college science learning and teaching, there is uneven integration of these social science perspectives into the pre-college science curriculum (Lederman, 1999, 2013; McComas, 2014; Rudolph, 2000). The research suggests that pre-college lessons related to teaching evolution, especially human evolution, should utilize these social science perspectives for students to undergo conceptual change such to garner greater and more accurate conceptual understandings of human evolution (National Academy of Sciences, 1998).

To accommodate for deficiencies in the teaching of evolution in formal pre-college science, educational outlets like museums and science centers have taken actions to aid teachers in presenting concepts related to human evolution (Diamond \& Evans, 2007), namely by creating and sharing pre-college science lesson plans on human evolution. These lesson plans are not only derived from informal sources, but also formal science teaching organizations, as well as governmental, university, and scientific entities with vested interests in promoting human evolution education. Since human evolution is not a part of national pre-college science standards (National Research Council [NRC], 2012), pre-college teachers who choose to teach human evolution in their science classes are likely to source their lesson plans from these online resources as vetted content experts in human evolution knowledge and outreach. However, it is not currently understood to what extent, if any, that these lesson plans employ researched-based best practices (e.g. presenting a variety of direct and indirect evidence, employing aspects of the NOS and SSI social science perspectives) to foster the conceptual change necessary to positively augment students' knowledge of human evolution. Thus, the intent of this research was to analyze pre-college lesson plans from entities that exert content leadership in human evolution and create online lesson plans targeted to pre-college science teachers. Identifying the types of evidence presented and presence of social science perspectives (together referred to as best practices) provides a proxy measure for sampled lessons' capabilities to foster conceptual change, which is needed for students to generate robust understandings of human evolution. In taking a census of the evidentiary strategies and social science approaches among these select lesson plans, we may garner a better understanding to the quality of the current resources made for pre-college teachers to teach human evolution. Findings can help provide guidance to lesson plan developers in creating lessons and teacher-practitioners in selecting resources for best practices to best teach this complex, intriguing, and incredibly important science concept.

\section{Literature review}

To understand why lesson plans was selected as the lens of analysis warrants first a review of the literature on the key factors that facilitate pre-college evolution education, which include science standards and science teachers. Areas of concern, and thus prior research, have largely centered on religious and community-based issues in precollege evolution education (Griffith \& Brem, 2004; Meadows, Doster, \& Jackson, 2000; Smith, 2010). Yet, this research instead focuses on what is presented within the classroom, situated within standards and teaching, such to better illuminate the importance of lesson plans themselves in utilizing best practices (i.e. varied evidence and social science perspectives) for teaching human evolution.

In American pre-college science education, national and state standards largely drive what is taught in the classroom (Krajcik, McNeill, \& Reiser, 2008). Therefore, an effort to improve American science education at its source (i.e. via national standards) yielded A Framework for K-12 Science Education: Practices, Crosscutting Concepts, and Core Ideas (NRC, 2012); a publication intended to provide guidance in developing robust standards for teaching pre-college classroom science. The inevitable result of this work was the Next Generation Science Standards (NGSS Lead States, 2013), the 
most recent iteration and extensive set of national level standards for K-12 science (and engineering) content and practices. It is important to note that the NGSS does state that "biological evolution explains both the unity and the diversity of species and provides a unifying principle for the history and diversity of life on Earth" (NGSS Lead States, 2013, p. 161), but does not contain any language specifically recognizing human evolution. However, both the National Academy of Sciences (1998) and the National Academy of Sciences and Institute of Medicine (2008) has provided guidance regarding content and contextual examples appropriate for pre-college students' to understand the underlying concepts of human origins: providing explanations using varied sources of evidence (e.g. data) that supports common ancestry and use of current models (e.g., phylogenetic trees) of modern human evolution. Although there is a mention within the NGSS of a misconception alert regarding evolution from extant primates versus a common ancestor, the specific phrase 'human evolution' is not found in the NGSS (NGSS Lead States, 2013). Although not all states use the NGSS, the topic of evolution is covered in each of the 50 state's science standards (Swanson, 2005); notably the breadth and depth of evolution topics vary among the states and even from year to year (Skoog \& Bilica, 2002). According to a white paper by Lerner, Goodenough, Lynch, Schwartz, and Schwartz (2012) that graded states' science standards, only four states (i.e., Florida, Iowa, New Hampshire, and Rhode Island) delineated teaching human evolution in their state science standards. Clearly there is a strong desire for evolution education in standards (Watts, Levit, \& Hoßfeld, 2016), yet explicit standards for teaching human evolution remain largely absent among national and state science standards. Overall, national and state science standards are important, although some researchers suggest what teachers teach is directly influenced by the standards (Spillane, 2002), while others contend that the standards do not (Berkman \& Plutzer, 2011; Fowler \& Meisels, 2010; Loveless, 2012; Moore, 2002). These latter findings open the door for the pre-college teaching of human evolution, despite not being distinctly mandated by most pre-college science standards.

Regardless of science standards being used as authority or auxiliary, pre-college science teaching is grounded in content-specific curriculum (Schmidt, Wang, \& McKnight, 2005) and instruction (Kesidou \& Roseman, 2002). Lesson plans form the 'core component of [precollege] teacher practice' (Schwarz et al., 2008, p. 346). Glatthorn (2000) has mapped the strength of influences among the various types of curriculum to what is taught (enacted) in the classroom. He had illuminated a weak relationship between teachers' planned (or as he termed written) curriculum to what is taught. However, he noted a strong influence of supported curriculum, or external resources provided to teachers, to what is taught in the classroom. Glatthorn, Boschee, Whitehead, and Boschee (2018) elaborated that this strong influence derives from the vetted and detailed information these materials provide to support student engagement and learning. Further, they described how cost of this curriculum stymies procurement of these materials and harms student learning, stating that "this conundrum is of paramount importance and is clearly critical if future generations of children are to remain educationally, socially, and economically competitive on a global level" (p. 11).

Lesson plans sourced from the supported curriculum take the form of student handouts, step-by-step teacher guides, often including physical materials and media, describing in great detail what students should/do learn within the science classroom. Because of the nature of lesson plans described here, it must be acknowledged that the science teacher themselves are too significant, being the primary agent of which of these lessons are chosen and how they are taught in the classroom (Olson, 1980). Remillard (2005, p. 236), conceptualizes the relationship between teachers and curriculum as "participatory," where teachers both interpret and draw upon curriculum, such that the curriculum itself does not fully encapsulate its teaching (or fidelity of implementation). Therefore, in the context of this study, the lesson plan represents the planned curriculum that shapes what may occur (rather than guides or direct what will occur) within the classroom, given variability of teachers' implementation of the lesson plan (as enacted curriculum).

How a science teacher interprets lesson plan is a function of their pedagogical content knowledge or PCK (Henze \& Van Driel, 2015), which is largely sourced from his or her wisdom of practice or prior classroom teaching experiences (Shulman, 1987). This is important to note as the numbers of veteran science teachers (defined as ten or more years of classroom teaching experience) are decreasing, and nearly half (42\%) hold fewer than 9 years of teaching experience (National Science Board [NSB], 2016) with only moderate increases in the past few years (NSB, 2018). Among the ranks of new and novice teachers, who may lack the knowledge and skills to create their own quality curriculum, are likely to solely rely on lesson plans (from supported curriculum) for their planned curriculum and instruction (Mulholland \& Wallace, 2005; Schwarz et al., 2008). These statistics may reflect why supported curriculum, especially from agency and grant funded sources (Roblin, Schunn, Bernstein, \& McKenney, 2018) are providing vital supports for science teachers in fostering conceptual understandings for their students (Roblin, Schunn, \& McKenney, 2018). 
In both evolution and specifically human evolution, effective preparation for science teachers' understanding remains to be determined (Nehm \& Reilly, 2007), therefore the reliance on scaffolding understanding and presentation of materials in human evolution-focused lesson plans is paramount. Lesson plans, sourced from the supported curriculum that are grounded in best practices for teaching evolution may help to mitigate findings from a survey conducted by Rutledge and Warden (2000) that indicated teachers held poor understandings of mechanisms of evolution; which influence students' learning of this topic (McNeill \& Krajcik, 2008). Considering that pre-college curriculum and instruction is inextricably linked to standards, which are also tied to assessment (Corrigan, Gunstone, \& Jones, 2013), the lesson plans available for teachers from supported curricular resources greatly influences the presented information and activities within the pre-college science classroom at large (Sickel, Banilower, Carlson, \& Van Driel, 2015; Weiss, Pasley, Smith, Banilower, \& Heck, 2003). And, that certain supported curricular lesson plans are developed by a consortium of experts (e.g. experienced teachers, science education researchers, and content experts), they best represent current approaches for teaching pre-college science.

\section{Theoretical framework}

Despite being notably absent from most science standards, the teaching of evolutionary concepts has great practical value for pre-college students (National Academy of Sciences, 1998). Therefore, there is a need to explore how curriculum materials, specifically for precollege teachers, are designed to foster pre-college students' understandings and acceptance of human evolution. This concept is known as conceptual change; Posner et al. (1982) posited that for conceptual change to occur, students must have their initial ideas challenged by a preponderance of evidence (direct and indirect) and compelling ideas (NOS and SSI) such that these new ideas presented provide better explanations for scientific phenomena. Without a variety of evidentiary sources and contextual ideas, students may rely on prior knowledge to source their understandings and acceptance of evolution that is incomplete or erroneous. This may, in part, explain why $65 \%$ of American men and $55 \%$ of American women believe humans have evolved other time as compared to $66 \%$ of American men and $60 \%$ of American women who believe animals have evolved over time (Pew Research Center, 2013). Students are innately drawn to human evolution as it is an exploration of themselves, which is engaging (Nelson, 2012) and increasing students' interests in and perceived relevance of human evolution (Schrein, 2014). Research suggests that teaching evolution, with human examples, can aid students' understanding of macroevolution and elements of the NOS (Nelson, 2008; Pobiner, 2016). For these reasons, pre-college teachers may elect to teach at least one of their lessons on evolution using humans as an example (Nelson, 2008; Pobiner, 2016). Further, findings have shown that historically based lessons (SSI) enriched with problem solving attributes (NOS) led to improved student understandings of evolution (Andersson \& Wallin, 2006; Dagher \& BouJaoude, 1997; Jensen \& Finley, 1997). Lessons grounded in NOS and SSI using varied sources of direct and indirect evidence to enhance students' understandings of evolution (Dagher \& BouJaoude, 1997; Nehm \& Schonfeld, 2007; Rutledge \& Mitchell, 2002; Rutledge \& Warden, 2000). Considering the chequered past in misuse of human evolution research (e.g., eugenics, phrenology) and racial undertones of evolution denial (e.g. denial of fossils derived from Africa), accentuating NOS and SSI perspectives can provide vital historical and social context; not only for learning evolutionary concepts but also truly understanding how this evolutionary knowledge came to be and the sociocultural conditions of its controversy. Arguably, social science perspectives, like NOS and/or SSI, should be a part of any lesson plan intended to present science concepts, especially those related to human evolution.

Last, for pre-college teachers who do choose to teach human evolution, it is unlikely they will use multiple lesson plans, instead opting to select one lesson within a larger evolution unit (Nelson, 2008; Pobiner, 2016). Therefore, it is important to acknowledge how each lesson plan incorporates evidentiary diversity and social science perspectives as best practice in fostering conceptual change. In doing an analysis of the extant, available human evolution lesson plans from experts in the supported curriculum, we may garner insight to what extent diverse evidence is presented and social science concepts employed to foster conceptual change (Posner et al., 1982), and robust learning of human evolution, for precollege students in science classrooms across the United States.

\section{Materials and methods}

In the research literature, there have been robust analyses of evolution curriculum, such as exploring science standards as enacted curriculum, through textbook analyses (Moore, 2002; Shankar \& Skoog, 1993; Skoog, 1979, 1984, 2005; Skoog \& Bilica, 2002). This methodology is a similar style of analysis, using content analysis to examine pre-college lesson plans as planned activities for the teaching of human-related evolution. This study sought to understand the types of evidence of evolution presented and to what extent (if any) social science perspectives were employed to teach human evolution. 
In order to maintain the focus on human evolution, only a select group of salient concepts related to (the teaching of) human evolution were considered, those with empirical relationships in fostering conceptual understanding (learning, varied evidence) and change (acceptance, social science perspectives). In examining sampled precollege focused lesson plans freely available online from vetted sources for pre-college science teaching on human evolution, to what extent does the planned curricula contain elements that foster conceptual change for understanding human evolution, such as: (1) what types of (direct and indirect) evidence are presented?, (2) what proportion of these lesson plans provide varied evidence (i.e. direct evidence only, indirect evidence only, or both direct and indirect evidence)?, and (3) to what degree, and in what ways, are social science perspectives, such as NOS and SSI, utilized?

\section{Data selection}

Lesson plans detail the student learning activity (the enacted curriculum) for students to complete (Leinhardt \& Greeno, 1986), by outlining explicitly to the teacher the student learning objectives or outcomes (Kauchak \& Eggen, 2012). Research suggests that teachers use lesson plans as is, with little to no modification (Recker, Dorward, \& Nelson, 2004). This lends well to justifying the use of the lesson plan as the unit of analysis, as it can serve as a proxy for classroom activity, demonstrating the specific content of the activity for students and how it would be presented by the teacher (Longfield, 2015).

\section{Criteria justification}

Unit selection (Duncan, 1989) was based upon the available resources from which science teachers would likely draw upon to teach concepts related to human evolution. Although there are printed lesson plans, online lesson plans have grown in popularity with pre-college science teachers due to the greater accessibility of the internet, unavailability of print resources availed to them locally, being no- to low-cost, have advantages in being up-to-date, and can also leverage online tools (e.g., simulations, videos); online resources not only engage students, but also convey robust understandings of evolution (Linn, Davis, \& Bell, 2004; Lui \& Slotta, 2014). In addition, research suggests teachers gravitate to online resources on evolution as print resources, like textbooks, may be outdated or provide misinformation (Fulford \& Rudge, 2016; Tshuma \& Sanders, 2015). Notably, the scope of the research questions does not pertain to student learning; focusing instead on the content (evidence) and perspectives (NOS and SSI) within human evolution lesson plans. Therefore, for this exploratory study, lesson plans sourced from experts (with the vetted, supported curriculum) were chosen as the unit of analysis.

\section{Selection criteria}

Lesson plans on human evolution (units) selected were available in 2016 and 2017 (when the research study was conducted), and downloaded from free (no-cost), online, and vetted sources. There are some human evolution lesson plans available to teachers through paid curricular resources, yet most vetted sources offered free lesson content. Lesson plans included both physical (requiring materials that the teacher would need to physically prepare) and virtual (requiring hardware and software of a typical, personal computer with internet access) activities. Online search criteria included the terms: human evolution, lesson plans, and curriculum resources. Lesson plans that satisfied search parameters were then further scrutinized to ensure they were 'vetted,' either recommended by American science teacher organizations (i.e. NSTA), or produced by trustworthy organizations with knowledge of human evolution (i.e. governmental, university, or scientific agencies). Last, each lesson plan was verified to ensure it was intended to be used for pre-college students by a pre-college science teacher. Each resource was carefully catalogued into the data set by the (1) original lesson plan developer to acknowledge the vetting of its source, (2) full title of the lesson plan to ensure it related specifically to human evolution (and not evolution in general), and (3) full uniform resource locator (URL) to prevent any redundancy in data collection for analysis. Data collection ended when saturation occurred, meaning lesson plans were no longer unique (repeated at several resources) or lessons began to not fit the research parameters (lesson plans on evolution, but not specific to human evolution). Additional resources (e.g. student handouts, notes) were examined only to ensure proper interpretation of the lesson plan, but they neither coded nor recorded. In all, 86 unique lesson plans were identified, collected, coded and analyzed, all of which were recommended or developed by 18 different teacher associations, science-focused non-profit organizations, and governmental agencies. A complete list of these sources can be found in Appendix.

\section{Analysis}

The collected lesson plans were coded using a deductive content analysis approach (per Hesse-Biber, 2016). The study began with relevant research on human evolution as guidance in establishing category and subcategory codes (Hsieh \& Shannon, 2005). This benchmarking strategy helped to reduce researcher bias by clarifying the extant lines of direct and indirect evolutionary evidence lesson plans may employ for the teaching of human evolution (Swanson, 2005). Seven categories 
(codes) were established from the lines of evidence for human evolution from the Smithsonian National Museum of Natural History (2018), the National Research Council's National Science Education Standards (1996), the National Academy of Sciences (1999), and the National Center for Science Education (Nickels, 1998) as geologic age, behavior, biochemical, biogeography, common ancestry, and Hominid-based fossils. In the coding process, subcodes were identified within each evidence type (category or main code) to provide more visualization to the data. Origin of the sub-codes were derived from the lessons themselves. For example, if the lesson was to create a cladogram related to common ancestry, that subcode was recorded for that lesson; if the lesson was about molecular clocks, that subcode was recorded. For lessons that overlapped in evidence (e.g. phylogenetics and phylogeny for example), multiple codes and subcodes were applied.

Next, social science perspectives (NOS and SSI) were added as constructs of interest within the study. If lesson plans presented explicit connections to NOS (see NRC, 1996) or SSI (see Zeidler, Sadler, Simmons, \& Howes, 2005) as described in the literature review, they were coded as such. For example, in addition to what type of evidence presented, if any lesson plan that connected evolution content to social science perspectives (Barton, 1998; Regal, 2004) they were coded as such. Coding for NOS recognized the inherently broad and intertwined nature of "understanding science as a way of knowing" (McComas, 2017, p. 71) or as the values and beliefs to develop of scientific knowledge (Lederman, 1992). Coding for lesson plans examined if they focused specifically on attributes, characteristics, values or assumptions related to the NOS, such as: how we come to understand science, discerning observations compared to inferences, understanding the construction of theories using data. In respecting prior NOS scholarship that states "no consensus presently exists among philosophers of science, historians of science, scientists, and science educators on a specific definition for NOS" (Abd-El-Khalick \& Lederman, 2000, p. 666) and NOS elements in lessons are integrated and not easily disentangled, no subcodes were developed for the NOS category. Further, this decision aligns to the research inquiry, which was to ascertain the explicitness of NOS within the lesson plan, rather than make any assessments to the quality of NOS integration. However, since SSI can be parsed using sociocultural boundaries (Zeidler et al., 2019), racial and historical perspectives became the two subcodes that emerged from the data. A summary of these seven categories and respective subcategories are found in Table 1.

\section{Trustworthiness}

To meet the standards of high-quality qualitative work, the following standards of credibility, transferability,
Table 1 Seven types of evidence (categories, codes) and examples (subcategories, sub-codes) in teaching for conceptual change in human evolution within pre-college science

\begin{tabular}{|c|c|}
\hline Categories (Codes) & Subcategories (Sub-codes) \\
\hline \multirow[t]{3}{*}{ Age (Geology) } & Relative Age: Biostratigraphy \& Biochronology \\
\hline & Absolute Age: Radiometric Dating \\
\hline & Geologic Time/Scale \\
\hline \multirow[t]{5}{*}{ Behavior } & Tool or Weapon Making (Hunting or Cooking) \\
\hline & $\begin{array}{l}\text { Art or Language (Drawing, Music, Jewelry, } \\
\text { or Clothing) }\end{array}$ \\
\hline & $\begin{array}{l}\text { Agricultural Revolution: Food Storage/ } \\
\text { Domestication/Settlements }\end{array}$ \\
\hline & $\begin{array}{l}\text { Behavioral similarities to non-human extant } \\
\text { Primates }\end{array}$ \\
\hline & $\begin{array}{l}\text { Affective Processes (Social Bonds, Feelings, } \\
\text { Religion, or Ceremonial Burial) }\end{array}$ \\
\hline \multirow[t]{5}{*}{ Biochemical Evidence } & Chromosome/DNA/RNA Comparison \\
\hline & Evolutionary Genetics \\
\hline & Phylogenetics \\
\hline & Hybridization \& Interbreeding \\
\hline & Molecular Clocks \\
\hline \multirow[t]{2}{*}{ Biogeography } & Regional Hypotheses \\
\hline & Multiregional Hypotheses \\
\hline \multirow[t]{5}{*}{ Common Ancestry } & $\begin{array}{l}\text { Comparative Anatomy (structural similarities) } \\
\text { to extant primates }\end{array}$ \\
\hline & $\begin{array}{l}\text { Homology or Analogy (structural similarities) } \\
\text { to extant non-primates }\end{array}$ \\
\hline & Comparative Embryology \\
\hline & Cladistics and Phylogeny \\
\hline & Vestigial Structures \\
\hline \multirow{3}{*}{$\begin{array}{l}\text { Hominid-based } \\
\text { Fossils }\end{array}$} & Skull Comparison (brain or jaw size) \\
\hline & Skeletal Comparisons (bipedalism) \\
\hline & $\begin{array}{l}\text { Other Fossils (including footprints, molds } \\
\text { and casts) }\end{array}$ \\
\hline $\begin{array}{l}\text { Social Science } \\
\text { Perspectives }\end{array}$ & $\begin{array}{l}\text { Nature of Science SocioScientific Issues } \\
\text { (History and Race) }\end{array}$ \\
\hline
\end{tabular}

confirmability, and dependability were addressed in the planning and execution of the research (Guba, 1981; Shenton, 2004). An advantage of using a deductive process is that there is abundant knowledge about the phenomenon (Elo \& Kyngäs, 2008) and a clear domain of knowledge from which to structure, organize, and draw meaning from the data set (Hickey \& Kipping, 1996), providing credibility. Ascertaining information that was strictly relevant to the research questions were how the categories became represented within the data set (Hesse-Biber, 2016). Therefore, using a coding schema sourced from the latest and most relevant research from the (human evolution) scientific community was central to establishing trustworthiness in this method (Folger, Hewes, \& Poole, 1984). In regard to 
transferability or generalization to the larger data set, a transparency process for data saturation ensured the data set $(N=86)$ was representative of the lesson plans available (online) to pre-college science teachers teaching human evolution from entities recognized as content experts that develop pre-college lesson plans for science teachers. Confirmability or objectivity was ensured through a wide sampling method, collecting from 18 different resources meeting selection criteria (see
Appendix) and using coding established from the research community, (i.e., the Smithsonian National Museum of Natural History the National Research Council's National Science Education Standards, the National Academy of Sciences, and the National Center for Science Education). Dependability was established using a transparent data collection protocol (Appendix), coding schema (Table 2), and multiple coders. Intercoder reliability was performed to evaluate

Table 2 Descriptive statistics for types of evidence in human evolution lesson plans $(N=86)$

\begin{tabular}{|c|c|c|c|c|}
\hline $\begin{array}{l}\text { Evidence For Teaching Human Evolution } \\
\text { (Categories and Subcategories) }\end{array}$ & $n$ & $\begin{array}{l}\text { Category Percentage from } \\
\text { Category Frequency } \\
(\boldsymbol{n}=176)\end{array}$ & $\begin{array}{l}\text { Sub-category Percent Within } \\
\text { Parent Category (Totals) }\end{array}$ & $\begin{array}{l}\text { Percentages of Categories and } \\
\text { Sub-categories within Total } \\
(\boldsymbol{n}=426)\end{array}$ \\
\hline Hominid-based Fossils & 54 & 30.7 & - & 12.7 \\
\hline Skull Comparison (Brain or Jaw Size) & 31 & & 37.8 & 7.3 \\
\hline Skeletal Comparison (Bipedalism) & 27 & & 32.9 & 6.3 \\
\hline Other Fossils (Footprints/Molds/Casts) & 24 & & 29.7 & 5.6 \\
\hline Common Ancestry & 22 & 12.5 & - & 5.2 \\
\hline Homology or Analogy (to extant non-primates) & 5 & & 17.2 & 1.2 \\
\hline Cladistics & 7 & & 24.1 & 1.6 \\
\hline Vestigial Structures & 1 & & 3.4 & 0.23 \\
\hline Comparative Embryology & 1 & & 3.4 & 0.23 \\
\hline Comparative Anatomy (to extant primates) & 15 & & 51.7 & 3.5 \\
\hline aBiochemical & 34 & 19.3 & - & 8.0 \\
\hline Chromosomes/DNA/RNA Comparison & 18 & & 32.1 & 4.2 \\
\hline Evolutionary Genetics (Heredity) & 16 & & 28.6 & 3.8 \\
\hline Phylogenetics (Phylogeny) & 16 & & 28.6 & 3.8 \\
\hline Hybridization or Interbreeding & 3 & & 5.4 & 0.70 \\
\hline Molecular Clocks & 2 & & 3.6 & 0.47 \\
\hline${ }^{a}$ Age (Geology) & 16 & 9.1 & - & 3.8 \\
\hline Relative Age: Biostratigraphy \& Biochronology & 11 & & 55 & 2.6 \\
\hline Absolute Age: Radiometric Dating & 3 & & 15 & 0.70 \\
\hline Geologic Time / Scale & 5 & & 25 & 1.2 \\
\hline Biogeography & 11 & 6.25 & - & 2.6 \\
\hline Regional Hypotheses & 11 & & 78.6 & 2.6 \\
\hline Multiregional hypotheses & 2 & & 14.3 & 0.47 \\
\hline Hominid Behavior & 24 & 13.6 & - & 5.6 \\
\hline Tools / Weapons: Hunting/Cooking & 17 & & 65.4 & 4.0 \\
\hline Art or Language: Drawings/Music/Jewelry/Clothing & 10 & & 38.5 & 2.3 \\
\hline $\begin{array}{l}\text { Agricultural Revolution: Food Storage/ } \\
\text { Domestication/Settlements }\end{array}$ & 3 & & 11.5 & 0.70 \\
\hline Affective Processes: Social Bonds, Feelings, Religion & 2 & & 7.7 & 0.47 \\
\hline Behavioral Similarities to other extant Primates & 3 & & 11.5 & 0.70 \\
\hline Social Science Perspectives & 15 & 8.5 & - & 3.5 \\
\hline Nature of Science & 13 & & 76.5 & 3.1 \\
\hline SocioScientific Issues (History) & 3 & & 17.6 & 0.70 \\
\hline SocioScientific Issues (Race) & 1 & & 5.9 & 0.23 \\
\hline
\end{tabular}

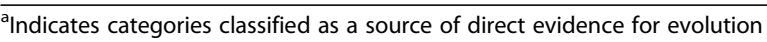


the efficacy of the coding schema in reaching the same conclusion (Lombard, Snyder-Duch, \& Bracken, 2002, 2010); ascertaining agreement to the type/s of evidence (categories and subcategories) within the lessons that were used to teach human evolution. A simple interrater or inter-coder agreement for categorical ratings was used to determine reliability (see Griffin, 2015). To ensure measurement consistency through intercoder or interrater agreement (Tinsley \& Brown, 2000), three raters with extensive experience teaching pre-college evolution and certified to teach high school level biology in three different states were selected to independently code $35 \%$ of the sample (i.e., 30 distinct lesson plans or units). Of the 30 units coded, approximately 63 codes and subcodes were created with $63.5 \%$ agreement between raters one and two; $81 \%$ agreement between raters two and three, and $82.5 \%$ agreement between raters one and three for a mean agreement of $76 \%$. Notably, there was no disagreement among raters regarding the seven categorical codes, rather disagreements (i.e. defined as any difference in coding, including missing codes, between any one of the three coders for any single subcode) stemmed from the 24 coded subcategories. Since units could have multiple subcodes, depending on the type of lesson activity, most disagreements stemmed from not having all potential subcodes applied. Resolution of disagreement occurred through conference, which involved the author discussing each 24 subcode disagreement with coders to ascertain the final subcodes. The remaining data (56 units) were coded using a single coder.

There are limitations to be acknowledged in employing this methodology and focus within this research study. First, not every single lesson plan on human evolution available to pre-college science teachers were analyzed, especially those that required purchase to access. Second, an assumption was made that sampled outlets (listed in Appendix) are recognized 'experts' in human evolution (content), although they may not hold the same expertise in formal science education. However, the sampled lesson plans were bounded by supported curriculum outlets who claim to carefully craft their lesson from vetted content, conduct expert review (often with teachers), and are tested in precollege classrooms. Nevertheless, these sources are producing curriculum as well as professional development, newsletters and non-lesson resources, which are geared specifically to pre-college science teachers (Smithsonian Institution, n.d.). Therefore, regardless of how these entities perceive themselves as content and/or pedagogical leaders, they are purposefully engaging with pre-college science teachers, which warrants a critical view to ascertain the alignment of the lessons they produce to research-based best practices in pre-college human evolution teaching and learning. Second, due to the use of a specific theoretical frame and research intent, the analysis intended to quantify, not qualify, best practices. Notwithstanding, a third limitation is that this study purposefully made no assessments to how evolutionary evidence and social science perspectives were actualized through instruction. With any supported curriculum, teachers may "misinterpret, subvert, and even ignore" elements of the curriculum in their classroom practices (Remillard, 2005, p. 212). Given the controversial nature of human evolution in America (Lederman \& Lederman, 2019), pre-college teachers' perceptions of this content may shape their perceptions and alter the intended implementation of these lessons in an actual classroom setting (Remillard \& Bryans, 2004).

\section{Results}

Before presenting the results of the content analysis, a brief discussion is warranted to provide insight to how these 18 sampled organizations created and vetted their lesson plans for the accuracy of their scientific content and use of age appropriate pedagogies. A university connected organization, ENSIWEB (2020, para. 1) at Indiana University, stated that their lessons were "developed and tested during 10 years of summer institutes by biology teachers from across the nation," and were maintained by a team of ENSI biologists and anthropologists, with financial support from the National Science Foundation (NSF). Similarly, The Smithsonian Institution (a governmental organization) developed their human evolution lessons with research scientists and museum educators, also supported by NSF grants. Further, The Smithsonian Institution regularly reviews each lesson plan on their site for "both content accuracy and pedagogical best practices" (B. Pobiner, personal communication, August 21, 2020). The Public Broadcasting Service (PBS) NOVA evolution project (2001) enlisted teams of scientists and science educators to serve as advisors, who guided the development of their video series and subsequent lesson plans. The National Science Teaching Association [NSTA] (2020) vets the lesson plans published in their books and journals using a process of double-blind peer review. Furthermore, all NSTA publication venues and their procedures are overseen by a series of Publication Advisory Boards, which are charged with selecting and vetting appropriate referees with the qualifications to assess submitted manuscripts for accuracy of content and pedagogical rigor.

To garner an understanding of the types of information presented about human evolution within the sampled lesson plans, descriptive statistics were used to summarize codes. Table 2 shows the frequency in 
which the 86 selected lesson plans presented a concept (a priori categories and emergent subcategories) on human evolution, and if it held a social science perspective. Category frequencies (and percentages) were established to demonstrate the type of lesson (evidence presented to teach human evolution) most prevalent within the sample. From these seven categories, Hominid-based fossils made up the majority of categories (30.7\%), followed by biochemical evidence (19.3\%), hominid behavior (13.6\%), common ancestry (12.5\%), age (geology) (9.1\%), social science perspectives (8.5\%), and biogeography (6.25\%). Subcategory frequencies were also determined to understand how sub-categorical evidence was represented within the corresponding major categorical evidence. Most categories had uneven distributions of subcategory representation, the most occurring in biogeography (regional hypotheses were $78.6 \%$ of category total) and social science perspectives (notably NOS was $76.5 \%$ of the category total). The most abundant evidence by subcategory within the sample was skull comparisons (7.3\%), skeletal comparisons (6.3\%), and other fossils (5.6\%), all of which were in the hominid-based fossil category (12.7\%).

To view what types of evidence was represented within the data set, Table 3 displays the analyzed distribution of evidentiary diversity. What comprised direct (i.e. biochemical evidence and age) and indirect (i.e. hominid-based fossils, biogeography, and evidence of hominid behavior) categories was directly informed by the community of practice (NSTA, 2000; Smithsonian National Museum of Natural History, 2018). Notably, direct and indirect evidence share equal importance in the scientific community regarding evidence for evolution; so the pre- these demarcations have been made within the pre-college education community for instructional purposes only (National Academy of Sciences, 1999, p. 27). Therefore, they are thusly partitioned in this study to add visualization, given both are equally important in fostering conceptual change. Of these 86 lesson plans, nine presented direct evidence only (10\%), 52 presented indirect evidence only (61\%), and 25 presented a combination of both direct and indirect evidence (29\%).

Of the nine lesson plans that presented direct evidence, it was found that all nine presented only one piece of evidence for human evolution. There was more diversity within the indirect evidence lesson plans $(n=$ $52)$, in presenting one $(n=25)$, two $(n=20)$, three $(n=4)$, and up to four $(n=2)$ types of evidence for human evolution. For the 25 lessons that adhered to best practice in presenting both direct and indirect evidence for the teaching of human evolution, most lesson plans used a mix of three $(n=11)$, two $(n=8)$, four $(n=4)$, five $(n=1)$ and up to six pieces of evidence, respectively.

Table 3 shows how many sampled lesson plans had followed recommended best practices in teaching human evolution by including a social science perspective $(n=$ 15). These 15 lesson plans also included two $(n=7)$, three $(n=4)$, or four $(n=3)$ types of direct and/or indirect evidence. Notably, only one lesson plan in this category named the NOS explicitly (as a pedagogical strategy) to present human evolution concepts.

A further analysis of the lesson plans, coded by social science perspectives, is found in Table 4. Social science perspectives were most pronounced within eight lesson plans and used as a supplement in six lessons. Most lesson plans in this subcategory employed a mixed presentation of direct and indirect evidence $(n=9)$ or indirect evidence only $(n=5)$. Eleven lesson plans in the social science category focused on NOS. These lessons provided scaffolded metacognitive activities for the learner to explore how scientific evidence is used to shape understandings of human evolution, making explicit the importance of observation and investigation to arrive at these conclusions. Three lessons incorporated SSI either through a blunt discussion of discrepant historical $(n=2)$ or racial $(n=1)$ perspectives in human evolution. These topics included the contentious aspects

Table 3 Distribution of types of evidence for 86 human evolution lesson plans

\begin{tabular}{|c|c|c|c|c|c|}
\hline & \multirow[t]{2}{*}{$n$} & \multicolumn{3}{|c|}{ Types of Evidence Presented in Human Evolution Lessons } & \multirow{2}{*}{$\begin{array}{l}\text { Used a Social } \\
\text { Science Perspective }\end{array}$} \\
\hline & & Direct & Indirect & Both & \\
\hline The Lesson Plans that presented: & 86 & 9 & 52 & 25 & 15 \\
\hline 1 type of evidence for evolution & 35 & 9 & 25 & 0 & 1 \\
\hline 2 types of evidence for evolution & 28 & 0 & 20 & 8 & 7 \\
\hline 3 types of evidence for evolution & 15 & 0 & 4 & 11 & 4 \\
\hline 4 types of evidence for evolution & 6 & 0 & 2 & 4 & 3 \\
\hline 5 types of evidence for evolution & 1 & 0 & 0 & 1 & 0 \\
\hline 6 types of evidence for evolution & 1 & 0 & 0 & 1 & 0 \\
\hline
\end{tabular}


Table 4 Descriptive statistics of the 15 lesson plans containing a social science perspective

\begin{tabular}{|c|c|c|c|}
\hline $\begin{array}{l}\text { Human } \\
\text { Evolution } \\
\text { Lesson Plan } \\
\text { with a Social } \\
\text { Science } \\
\text { Perspective }\end{array}$ & $\begin{array}{l}\text { Type of } \\
\text { Evidence } \\
\text { Presented in } \\
\text { the Human } \\
\text { Evolution } \\
\text { Lesson Plan } \\
\text { (Direct/Indirect/ } \\
\text { Mixed) }\end{array}$ & $\begin{array}{l}\text { Number of } \\
\text { Evidences } \\
\text { Present in the } \\
\text { Human } \\
\text { Evolution } \\
\text { Lesson Plan }\end{array}$ & $\begin{array}{l}\text { Type of Social } \\
\text { Science } \\
\text { Perspective(s) } \\
\text { Presentedin the } \\
\text { Human Evolution } \\
\text { Lesson Plan }\end{array}$ \\
\hline 1 & Mixed & 2 & NOS only \\
\hline 2 & Mixed & 3 & NOS and SSI (History) \\
\hline 3 & Mixed & 3 & NOS and SSI (History) \\
\hline 4 & Indirect & 2 & NOS only \\
\hline 5 & Mixed & 4 & NOS only \\
\hline 6 & Mixed & 2 & NOS only \\
\hline 7 & Indirect & 2 & NOS only \\
\hline 8 & Indirect & 2 & SSI (History) only \\
\hline 9 & Indirect & 2 & NOS only \\
\hline 10 & Mixed & 4 & NOS only \\
\hline 11 & Mixed & 3 & NOS only \\
\hline 12 & Mixed & 3 & SSI (Racial) only \\
\hline 13 & Mixed & 3 & NOS only \\
\hline 14 & Indirect & 4 & NOS only \\
\hline 15 & N/A & 1 & NOS only \\
\hline
\end{tabular}

The 3 categories of Social Science Perspectives included NOS and SSI, the latter of which related to Discrepant Historical and/or Racial Perspectives

of the discovery of $A$. africanus, a focus on the debate regarding primate-human evolution, and a confrontation of issues on race and skin color, respectively.

\section{Discussion}

The results of this research indicate that for the 86 online lesson plans for teaching human evolution available to pre-college science teachers, most $(n=52,60 \%)$ presented solely indirect evidence and most lesson plans $(n=63,73 \%)$ presented only one $(n=35)$ or two $(n=28)$ lines of evidence for human evolution. This result suggests a dearth of lesson plans using a diverse complement of evidence made available to pre-college teachers when teaching human evolution topic/s as best practice for fostering conceptual change in students (Posner et al., 1982). Sadler, Chambers, and Zeidler (2004) discovered when students made assessments of evidence for evolution, they considered diverse types of data to have greater explanatory powers, becoming a significant part of their decision-making process. These studies theoretically support that employing multiple sources of both indirect and direct evidence may provide students a greater threshold for understanding human evolution content, akin to Sadler and Fowler's (2006) threshold model of content knowledge transfer for SSI argumentation. Yet, this study's analysis yielded only a few lessons that presented a combination of evidence to teach human evolution. This research suggests that a strong knowledge base of evolution concepts, coupled with rich empirical data, influences learners' understanding of human evolution concepts. This calls for more thoughtful development in developing new lesson plans on human evolution that provide varied sources of evidence to pre-college science students.

This study also evidenced that few lesson plans (15 out of 86) leveraged some element/s social science perspectives, either NOS $(n=14)$ and/or SSI $(n=4)$. Research affirms when teachers use social science perspectives like NOS and SSI as a part of their instruction, students' content knowledge of evolution increases (Klosterman \& Sadler, 2010; Wongsri \& Nuangchalerm, 2010). In work by Lombrozo et al. (2008, p. 291), students who understood the NOS were able to "recogniz[e] the overwhelming evidence for evolution [and] may require an appreciation of the fact that evidence can come in many forms, result from diverse methods, and require inference and interpretation to bear on theories." Students' understandings of the NOS cultivates reasoning (Ford, 2008) that is reflective (Lawson \& Worsnop, 1992), evidentiary (Marsteller \& Bodzin, 2015), and transformational (Shtulman, 2006). This is significant as NOS, and related SSI interventions build skills like open-mindedness, which are helpful in understanding evolution (Harding \& Hare, 2000) and accepting evolution (Dunk, Petto, Wiles, \& Campbell, 2017; Fowler \& Zeidler, 2016).

It is noted again that this research was agnostic to the quality of the evidence and social science perspectives (NOS and SSI) presented, seeking first to quantify their existence in sampled lesson plans for teaching human evolution. As such, it was found that in addition to the heavy reliance on single pieces of indirect evidence for human evolution, there was also a lack of social science perspectives for students to engage with as they developed their understanding of human evolution. With the release of the NGSS (NGSS Lead States, 2013), American researchers had hoped that the NOS would find new life in pre-college science classrooms given its lackluster treatment in precursor science standards (McComas \& Nouri, 2016), stemming from NOS-specific recommendations its own Appendix $(\mathrm{H})$ of the NGSS. However, as scholars dug deeper into the NGSS and its documentation (Akerson, Carter, Pongsanon, \& Nargund-Joshi, 2019; Lederman \& Lederman, 2014, 2019), they were dismayed to find that "NOS recommendations in [the] NGSS fail to have 
the prominence of the other three main NGSS elements and [we] are therefore highly concerned that NOS may continue to be ignored or minimized by science teachers" (McComas \& Nouri, 2016, p. 572). Consequentially, NOS as an optional connection (Lederman \& Lederman, 2019) in the NGSS and other science standards is one of the many reasons that genuine NOS implementation has remained stymied in American K-12 science classrooms (Summers \& AbdEl-Khalick, 2019) and by extension, students fully learning human evolution. Without true NOS-based teaching and understandings, "students simply don't have the background understanding of the nature of science and evolutionary theory to be able to adequately evaluate the claims" (Smith, 2010, p. 563). In regard to SSI, similar findings hold, meaning that the teachers play a large role in the helping students negotiate SSI when learning evolutionary concepts (Fowler \& Zeidler, 2016), and without them harms students' conceptual understanding and acceptance of evolution. Thus, this research amplifies the call for the continued need for explicit incorporation of social science perspectives into science lessons on human evolution (Nickels \& Nelson, 1996). For this inclusion to be successful, this will require lesson plans to also provide specific pedagogical guidance for teachers who wish to employ social science perspectives, including the NOS and SSI, into their science instruction (Oulton, Day, Dillon, \& Grace, 2004; Saunders \& Rennie, 2013). This research identifies that lines of evidence and social science perspectives (best practices) are wanting in current body of lesson plan resources for pre-college teaching of human evolution.

\section{Conclusions and recommendations}

As mentioned at the start of the introduction, one of the most fundamental understandings within biology is evolution, yet often ascribed as one of the most misunderstood scientific concepts by the American public. Pre-college science teachers may choose to supplement the science standards on evolution by infusing human evolution topics by accessing lesson plans developed by content experts who develop and advertise these lessons to pre-college teachers. To ensure a robust understanding and appreciation of evolution per conceptual change theory (Posner et al., 1982), pre-college students should be provided with a variety of evidentiary sources (i.e. direct and indirect evidence for evolution) that emphases social science perspectives. Provided the extant call for strengthening evolution education through a focus on presentation of varied evidence and strengthening understanding through social science perspectives (Nelson, 2007; NRC, 2012), this research raises questions of not only rigorous content of such lessons, but also the pedagogical strengths of these resources. This question is important, if such sources (e.g., NOVA, Smithsonian, ENSI, among others listed in Appendix) posit themselves as producers of human evolution teacher resources, calls to question the responsibility of ensuring best practices in those curriculum materials. This research suggests areas of opportunity to embed these best practices when evaluating, selecting, revising, or developing new pre-college lesson plans on human evolution. The first recommendation for researchers is development of a rubric so scholars may extend this research to evaluate the quality of evolutionary evidence and social science perspectives presented within available lesson plans. Secondly, not only could this rubric evaluate to what extent best practices are represented, but also provide teachers a snap-shot understanding lesson quality, thereby aiding teachers in making more informed decisions to in selecting a single or complement of lessons for use in their classrooms. For curriculum development, the rubric may identify deficiencies in topic areas of (human) evolution (fewer lesson plans were found on topics related to age, biogeography, and common ancestry), guiding future curriculum design and provision of additional resources to address the dearth of those topic areas, especially as science standards grow more amenable to teaching evolution (Mead \& Mates, 2009). For entities that provide guidance to science teachers searching for existing lesson plans (like the NSTA) may wish to provide pre-college teachers and science specialists (e.g., coaches, directors) with technical assistance like written guidance or curated resources, aiding them to select a suite of complementary lesson plans to ensure students are presented with a variety of evidence and social science perspectives from what is currently available. Provided that both experienced and especially growing numbers of novice science teachers rely on ready-to-use lesson plans (Henze \& Van Driel, 2015; NSB, 2016, 2018; Shulman, 1987), this creates opportunities for strengthening best practices by providing varied information (evidence) and embedded practices (NOS and SSI) for pre-college students to learn human evolution concepts. From these findings, future research could explore the other two elements that influence enacted curriculum: how a teacher employs curriculum resources and the resulting classroom practices, vis-à-vis human evolution. Such a study would address needs and gaps in how curriculum is interpreted by teachers within their classroom practices (Remillard, 2005), and in an area of growing interest (human evolution) in pre-college science education. Further, future research may wish to explore how revised or new lesson plans, informed by these best practices, augment students' understandings of 
human evolution through an enhanced construction of accurate and comprehensive schemas, via conceptual change, on human evolution concepts and processes.

\section{Appendix}

Individual lesson plans $(N=86)$

Sources (in alphabetical order) $(N=18)$

British Broadcasting Corporation (BBC) $(n=1)$

Discovery Education $(n=3)$

E-Fossils - University of Texas $(n=1)$

Evolution \& Nature of Science Institute (ENSI)

(Indiana University) $(n=6)$

Exploratorium Museum $(n=1)$

JF Crow Institute for the Study of Evolution - University of Wisconsin at Madison $(n=3)$

Howard Hughes Medical Institute (HHMI) $(n=9)$

Institute of Human Origins (Arizona State University) $(n=5)$

National Center for Case Study Teaching in Science (University of Buffalo) $(n=2)$

National Geographic $(n=1)$

National Science Teachers Association (NSTA) Press $(n=7)$

NOVA by WGBH Boston $(n=28)$

Public Broadcasting Service (PBS) $(n=9)$

Science Magazine $(n=1)$

SciLinks with American Association for the Advancement of Science (AAAS) $(n=2)$

Smithsonian Museum of Natural History $(n=5)$

Talks Origins Archive $(n=1)$

Understanding Evolution (University of California Museum of Paleontology and the National

Center for Science Education) $(n=1)$

\section{Abbreviations}

NRC: National Research Council; NOS: Nature of science; NGSS: Next Generation Science Standards; SSI: Socioscientific issues; URL: Uniform resource locator

\section{Acknowledgements}

For their help in inter-coding and supporting the research, the author would like to acknowledge Drs. Gina Childers, Kristie Gutierrez, Kris Childs, and Elizabeth Kirman.

\section{Author's contributions}

$\mathrm{RH}$ conceptualized the research study, curated and coded the data as well as wrote and edited the manuscript. The author(s) read and approved the final manuscript.

\section{Authors' information}

Dr. Rebecca Hite is an assistant professor of science education at Texas Tech University.

\section{Funding}

There was no funding used in this research study and manuscript.

\section{Availability of data and materials}

The datasets generated and/or analysed during the current study are available in the Author Generated Human Evolution Lesson Plan repository, https://drive.google.com/file/d/1BgBVIIFoXjg6SMqbklqATOx9lb5HfUwo/ view? usp=sharing.
Ethics approval and consent to participate

Not Applicable.

\section{Consent for publication}

Not Applicable.

\section{Competing interests}

The author declares that they have no competing interests.

Received: 2 March 2020 Accepted: 25 August 2020

Published online: 11 September 2020

\section{References}

Abd-El-Khalick, F. (2003). Socioscientific issues in pre-college science classrooms. In D. L. Zeidler (Ed.), The role of moral reasoning and discourse on socioscientific issues in science education, (pp. 41-61). Dordrecht: Kluwer Academic Press.

Abd-El-Khalick, F., \& Akerson, V. L. (2004). Learning as conceptual change: Factors mediating the development of preservice elementary teachers' views of nature of science. Science Education, 88(5), 785-810.

Abd-El-Khalick, F., \& Lederman, N. G. (2000). Improving science teachers' conceptions of nature of science: A critical review of the literature. International Journal of Science Education, 22(7), 665-701.

Akerson, V. L., Carter, I., Pongsanon, K., \& Nargund-Joshi, V. (2019). Teaching and learning nature of science in elementary classrooms. Science \& Education, 28(3-5), 391-411.

Alters, B. J., \& Nelson, C. E. (2002). Perspective: Teaching evolution in higher education. Evolution, 56(10), 1891-1901.

American Association for the Advancement of Science. (2006). AAAS: Statement on the teaching of evolution. Retrieved from: http://archives.aaas.org/docs/ resolutions.php?doc_id=443

Andersson, B., \& Wallin, A. (2006). On developing content-oriented theories taking biological evolution as an example. International Journal of Science Education, 28(6), 673-695

Barton, R. (1998). Huxley, Lubbock, and half a dozen others: Professionals and gentlemen in the formation of the X Club, 1851-1864. Isis, 89(3), 410-444.

Bell, P., \& Linn, M. (2002). Beliefs about science: How does science instruction contribute? In B. Hofer, \& P. Pintrich (Eds.), Personal epistemologist: The psychology of beliefs about knowledge and knowing, (pp. 321-346). Mahwah: Lawrence Erlbaum Associates.

Berkman, M. B., \& Plutzer, E. (2011). Local autonomy versus state constraints: Balancing evolution and creationism in US high schools. Publius: The Journal of Federalism, 41(4), 610-635.

Biological Sciences Curriculum Study (2005). The nature of science and the study of biological evolution. Colorado Springs: Author.

Brem, S. K., Ranney, M., \& Schindel, J. (2003). Perceived consequences of evolution: College students perceive negative personal and social impact in evolutionary theory. Science Education, 87(2), 181-206.

Cobern, W. W. (1994). Comments and criticism. Point: Belief, understanding, and the teaching of evolution. Journal of Research in Science Teaching, 31(5), 583-590.

Corrigan, D., Gunstone, R. F., \& Jones, A. (2013). Valuing assessment in science education: Pedagogy, curriculum, policy. Dordrecht: Springer.

Dagher, Z. R., \& BouJaoude, S. (1997). Scientific views and religious beliefs of college students: The case of biological evolution. Journal of Research in Science Teaching, 34(5), 429-445.

Diamond, J., \& Evans, E. M. (2007). Museums teach evolution. Evolution: International Journal of Organic Evolution, 61 (6), 1500-1506.

Dobzhansky, T. (2013). Nothing in biology makes sense except in the light of evolution. The American Biology Teacher, 75(2), 87-92.

Duncan, D. F. (1989). Content analysis in health education research: An introduction to purposes and methods. Health Education, 20(7), 27-31.

Dunk, R. D., Petto, A. J., Wiles, J. R., \& Campbell, B. C. (2017). A multifactorial analysis of acceptance of evolution. Evolution: Education and Outreach, $10(1), 1-8$

Elo, S., \& Kyngäs, H. (2008). The qualitative content analysis process. Journal of Advanced Nursing, 62(1), 107-115.

ENSIWEB. (2020). What is ENSIWEB? Retrieved from: https://ensiweb.bio. indiana.edu/ 
Folger, J. P., Hewes, D. E., \& Poole, M. S. (1984). Coding social interaction. In B. Dervin, \& M. J. Voigt (Eds.), Progress in communication sciences, (pp. 115-161). Norwood: Ablex.

Ford, M. (2008). 'Grasp of practice' as a reasoning resource for inquiry and nature of science understanding. Science \& Education, 17(2-3), 147-177.

Fowler, S. R., \& Meisels, G. G. (2010). Florida teachers' attitudes about teaching evolution. The American Biology Teacher, 72(2), 96-99.

Fowler, S. R., \& Zeidler, D. L. (2016). Lack of evolution acceptance inhibits students' negotiation of biology-based socioscientific issues. Journal of Biological Education, 50(4), 407-424.

Fulford, J. M., \& Rudge, D. W. (2016). The portrayal of industrial melanism in American college general biology textbooks. Science \& Education, 25(5-6), 547-574.

Gelman, S. A., \& Rhodes, M. (2012). Two-thousand years of stasis. In K. S. Rosengren, S. K. Brem, E. M. Evans, \& G. M. Sinatra (Eds.), Evolution challenges: Integrating research and practice in teaching and learning about evolution, (pp. 200-207). New York: Oxford University Press.

Glatthorn, A. A. (2000). The principal as curriculum leader: Shaping what is taught \& tested, (2nd ed., ). Thousand Oaks: Corwin Press.

Glatthorn, A. A., Boschee, F., Whitehead, B. M., \& Boschee, B. F. (2018). Curriculum leadership: Strategies for development and implementation, (5th ed., ). Thousand Oaks: Sage Publications.

Griffin, B. W. (2015). Inter-rater agreement for nominal/categorical ratings. Retrieved from http://www.bwgriffin.com/gsu/courses/edur9131/content/ InterRater_nominal_codes.pdf

Griffith, J. A., \& Brem, S. K. (2004). Teaching evolutionary biology: Pressures, stress, and coping. Journal of Research in Science Teaching: Journal of Research in Science Teaching, 41(8), 791-809.

Guba, E. G. (1981). Criteria for assessing the trustworthiness of naturalistic inquiries. Ectj, 29(2), 75.

Harding, P., \& Hare, W. (2000). Portraying science accurately in classrooms: Emphasizing open-mindedness rather than relativism. Journal of Research in Science Teaching, 37(3), 225-236.

Hawley, P. H., Short, S. D., McCune, L. A., Osman, M. R., \& Little, T. D. (2011). What's the matter with Kansas?: The development and confirmation of the evolutionary attitudes and literacy survey (EALS). Evolution: Education and Outreach, 4(1), 117.

Henze, I., \& Van Driel, J. H. (2015). Toward a more comprehensive way to capture PCK in its complexity. In Re-examining pedagogical content knowledge in science education, (pp. 130-144). New York: Routledge.

Hesse-Biber, S. N. (2016). The practice of qualitative research: Engaging students in the research process. Los Angeles: Sage Publishing.

Hickey, G., \& Kipping, C. (1996). A multi-stage approach to the coding of data from open-ended questions. Nurse Researcher, 4(1), 81-91.

Hodson, D. (2014). Nature of science in the science curriculum: Origin, development, implications and shifting emphases. In International handbook of research in history, philosophy and science teaching, (pp. 911-970). Dordrecht: Springer.

Hsieh, H. F., \& Shannon, S. E. (2005). Three approaches to qualitative content analysis. Qualitative Health Research, 15(9), 1277-1288

Jensen, M. S., \& Finley, F. N. (1995). Teaching evolution using historical arguments in a conceptual change strategy. Science Education, 79(2), 147-166.

Jensen, M. S., \& Finley, F. N. (1996). Changes in students' understanding of evolution resulting from different curricular and instructional strategies. Journal of Research in Science Teaching, 33(8), 879-900.

Jensen, M. S., \& Finley, F. N. (1997). Teaching evolution using a historically rich curriculum \& paired problem solving instructional strategy. The American Biology Teacher, 59(4), 208-212.

Kampourakis, K., \& McComas, W. F. (2010). Charles Darwin and evolution: Illustrating human aspects of science. Science \& Education, 19(6-8), 637-654.

Kampourakis, K., Silveira, P., \& Strasser, B. J. (2016). How do preservice biology teachers explain the origin of biological traits?: A philosophical analysis. Science Education, 100(6), 1124-1149.

Kauchak, D. P., \& Eggen, P. D. (2012). Learning and teaching: Research-based methods. Boston: Allyn Bacon.

Kesidou, S., \& Roseman, J. E. (2002). How well do middle school science programs measure up? Findings from project 2061's curriculum review. Journal of Research in Science Teaching, 39(6), 522-549.

Klosterman, M. L., \& Sadler, T. D. (2010). Multi-level assessment of scientific content knowledge gains associated with socioscientific issues-based instruction. International Journal of Science Education, 32(8), 1017-1043.
Krajcik, J., McNeill, K. L., \& Reiser, B. J. (2008). Learning-goals-driven design model: Developing curriculum materials that align with national standards and incorporate project-based pedagogy. Science Education, 92(1), 1-32.

Lawson, A. E., \& Worsnop, W. A. (1992). Learning about evolution and rejecting a belief in special creation: Effects of reflective reasoning skill, prior knowledge, prior belief and religious commitment. Journal of Research in Science Teaching, 29(2), 143-166.

Lederman, N. G. (1992). Students' and teachers' conceptions of the nature of science: A review of the research. Journal of Research in Science Teaching, 29(4), 331-359.

Lederman, N. G. (1999). Teachers' understanding of the nature of science and classroom practice: Factors that facilitate or impede the relationship. Journal of Research in Science Teaching, 36(8), 916-929.

Lederman, N. G. (2013). Nature of science: Past, present, and future. In S. K. Abell, K. Appleton, \& D. L. Hanuscin (Eds.), Handbook of research on science education, (pp. 845-894). New York: Routledge.

Lederman, N. G., \& Lederman, J. S. (2014). Is nature of science going, going, going, gone? Journal of Science Teacher Education, 25, 235-238.

Lederman, N. G., \& Lederman, J. S. (2019). Teaching and learning nature of scientific knowledge: Is it Déjà vu all over again? Disciplinary and Interdisciplinary Science Education Research, 1(6), 1-9. https://doi.org/10.1186/ s43031-019-0002-0.

Leinhardt, G., \& Greeno, J. G. (1986). The cognitive skill of teaching. Journal of Educational Psychology, 78(2), 75

Lennox, J. G., \& Kampourakis, K. (2013). Biological teleology: The need for history. In K. Kampourakis (Ed.), The philosophy of biology, history, philosophy and theory of the life sciences, (pp. 421-454). Dordrecht: Springer.

Lerner, L. S., Goodenough, U., Lynch, J., Schwartz, M., \& Schwartz, R. (2012). The state of state science standards, 2012. Washington, DC: Thomas B. Fordham Institute.

Linn, M. C., Davis, E. A., \& Bell, P. (2004). Internet environments for science education. Mahwah: Lawrence Erlbaum Associates Inc.

Lombard, M., Snyder-Duch, J., \& Bracken, C. C. (2002). Content analysis in mass communication: Assessment and reporting of intercoder reliability. Human Communication Research, 28(4), 587-604.

Lombard, M., Snyder-Duch, J., \& Bracken, C. C. (2010). Practical resources for assessing and reporting intercoder reliability in content analysis research projects. Retrieved from http://matthewlombard.com/reliability/

Lombrozo, T., Thanukos, A., \& Weisberg, M. (2008). The importance of understanding the nature of science for accepting evolution. Evolution: Education and Outreach, 1(3), 290-298.

Longfield J. (2015). Lesson plan checklist. Retrieved from http://digitalcommons. georgiasouthern.edu/teaching-academy/54

Loveless, T. (2012). The common core initiative: What are the chances of success. Educational Leadership, 70(4), 60-63.

Lui, M., \& Slotta, J. D. (2014). Immersive simulations for smart classrooms: Exploring evolutionary concepts in secondary science. Technology, Pedagogy and Education, 23(1), 57-80.

Marsteller, R. B., \& Bodzin, A. M. (2015). The effectiveness of an online curriculum on high school students' understanding of biological evolution. Journal of Science Education and Technology, 24(6), 803-817.

Mayr, E. (1982). The growth of biological thought: Diversity, evolution, and inheritance. Cambridge: Harvard University Press.

McComas, W. F. (2014). Nature of science in the science curriculum and in teacher education programs in the United States. In M. Matthews (Ed.), International handbook of research in history, philosophy and science teaching, (pp. 1993-2023). Dordrecht: Springer.

McComas, W. F. (2017). Understanding how science works: The nature of science as the foundation for science teaching and learning. School Science Review, 98(365), 71-76

McComas, W. F., Clough, M. P., \& Almazroa, H. (1998). The role and character of the nature of science in science education. In The nature of science in science education, (pp. 3-39). Dordrecht: Springer.

McComas, W. F., \& Nouri, N. (2016). The nature of science and the next generation science standards: Analysis and critique. Journal of Science Teacher Education, 27(5), 555-576.

McNeill, K. L., \& Krajcik, J. (2008). Scientific explanations: Characterizing and evaluating the effects of teachers' instructional practices on student learning. Journal of Research in Science Teaching, 45(1), 53-78.

McVaugh, N. K., Birchfield, J., Lucero, M. M., \& Petrosino, A. J. (2011). Evolution education: Seeing the forest for the trees and focusing our 
efforts on the teaching of evolution. Evolution: Education and Outreach, $4(2), 286-292$

Mead, L. S., \& Mates, A. (2009). Why science standards are important to a strong science curriculum and how states measure up. Evolution: Education and Outreach, 2(3), 359-371.

Meadows, L., Doster, E., \& Jackson, D. F. (2000). Managing the conflict between evolution \& religion. The American Biology Teacher, 62(2), 102-107.

Moore, R. (2002). Teaching evolution: Do state standards matter? BioScience, 52(4), 378-381.

Mulholland, J., \& Wallace, J. (2005). Growing the tree of teacher knowledge: Ten years of learning to teach elementary science. Journal of Research in Science Teaching, 42(7), 767-790.

National Academy of Sciences (1998). Teaching about evolution and the nature of science. Washington, DC: The National Academies Press.

National Academy of Sciences (1999). Science and creationism: A view from the National Academy of Sciences, (2nd ed., ). Washington, DC: The National Academies Press.

National Academy of Sciences and Institute of Medicine (2008). Science, evolution, and creationism. Washington, DC: The National Academies Press.

National Center for Science Education. (2019). Evolution. Retrieved from https:// ncse.com/node/16774

National Research Council (1996). National science education standards. Washington, DC: National Academies Press.

National Research Council (2009). A new biology for the 21st century. Washington, DC: The National Academies Press. https://doi.org/10.17226/12764.

National Research Council. (2012). A framework for K-12 science education: Practices, crosscutting concepts, and core ideas. Committee on a Conceptual Framework for New K-12 Science Education Standards. Board on Science Education, Division of Behavioral and Social Sciences and Education. Washington, DC: The National Academies Press.

National Science Board (2016). Science and engineering indicators. Alexandria: National Science Foundation Report no.: NSB-2016-1.

National Science Board (2018). Science and engineering indicators. Alexandria: National Science Foundation Report no.: NSB-2018-1.

National Science Teaching Association. (2000). NSTA position statement on the nature of science. Retrieved from: https://www.nsta.org/about/positions/ natureofscience.aspx

National Science Teaching Association. (2013). NSTA position statement on the teaching of evolution. Retrieved from: http:/www.nsta.org/about/positions/ evolution.aspx

National Science Teaching Association. (2020). Advisory boards and panels. Retrieved from: https://www.nsta.org/advisory-boards-and-panels

Nehm, R. H., \& Reilly, L. (2007). Biology majors' knowledge and misconceptions of natural selection. BioScience, 57(3), 263-272.

Nehm, R. H., \& Schonfeld, I. S. (2007). Does increasing biology teacher knowledge of evolution and the nature of science lead to greater preference for the teaching of evolution in schools? Journal of Science Teacher Education, 18(5), 699-723.

Nelson, C. E. (2007). Teaching evolution effectively: A central dilemma and alternative strategies. McGill Journal of Education (Online), 42(2), 265.

Nelson, C. E. (2008). Teaching evolution (and all of biology) more effectively: Strategies for engagement, critical reasoning, and confronting misconceptions. American Zoologist, 48(2), 213-225.

Nelson, C. E. (2012). Why don't undergraduates really "get" evolution? What can faculty do. In Evolution challenges: Integrating research and practice in teaching and learning about evolution, (pp. 311-347).

NGSS Lead States (2013). Next generation science standards: For states, by states. Washington, DC: The National Academies Press.

Nickels, M. K. (1998). Humans as a case study for the evidence of evolution. Reports of the National Center for Science Education, 18(5), 24-27.

Nickels, M. K., \& Nelson, C. E. (1996). Better biology teaching by emphasizing evolution \& the nature of science. The American Biology Teacher, 58(6), $332-336$

Olson, J. K. (1980). Teacher constructs and curriculum change. Journal of Curriculum Studies, 12(1), 1-11.

Oulton, C., Day, V., Dillon, J., \& Grace, M. (2004). Controversial issues-teachers' attitudes and practices in the context of citizenship education. Oxford Review of Education, 30(4), 489-507.

Owens, D. C., Herman, B. C., Oertli, R. T., Lannin, A. A., \& Sadler, T. D. (2019). Secondary science and mathematics teachers' environmental issues engagement through socioscientific reasoning. Eurasia Journal of Mathematics, Science and Technology Education, 15(6), 1-27.
Pew Research Center. (2013). Public's views on human evolution. Retrieved from http://www.pewforum.org/2013/12/30/publics-views-on-human-evolution/

Pobiner, B. (2016). Accepting, understanding, teaching, and learning (human) evolution: Obstacles and opportunities. American Journal of Physical Anthropology, 159, 232-274.

Posner, G. J., Strike, K. A., Hewson, P. W., \& Gertzog, W. A. (1982). Accommodation of a scientific conception: Toward a theory of conceptual change. Science Education, 66(2), 211-227.

Public Broadcasting Service. (2001). About the project: Series credits. Retrieved from https:/www.pbs.org/wgbh/evolution/about/credits_series.html

Recker, M. M., Dorward, J., \& Nelson, L. M. (2004). Discovery and use of online learning resources: Case study findings. Journal of Educational Technology \& Society, 7(2), 93-104.

Regal, B. (2004). Human evolution: A guide to the debates. Santa Barbara: ABC-CLIO.

Remillard, J. T. (2005). Examining key concepts in research on teachers' use of mathematics curricula. Review of Educational Research, 75(2), 211-246.

Remillard, J. T., \& Bryans, M. B. (2004). Teachers' orientations toward mathematics curriculum materials: Implications for teacher learning. Journal of Research in Mathematics Education, 35(5), 352-388.

Roblin, N. P., Schunn, C., Bernstein, D., \& McKenney, S. (2018). Exploring shifts in the characteristics of US government-funded science curriculum materials and their (unintended) consequences. Studies in Science Education, 54(1), 1-39.

Roblin, N. P., Schunn, C., \& McKenney, S. (2018). What are critical features of science curriculum materials that impact student and teacher outcomes? Science Education, 102(2), 260-282.

Rudolph, J. L. (2000). Reconsidering the 'nature of science' as a curriculum component. Journal of Curriculum Studies, 32(3), 403-419.

Rutledge, M. L., \& Mitchell, M. A. (2002). High school biology teachers' knowledge structure, acceptance \& teaching of evolution. The American Biology Teacher, 64(1), 21-28.

Rutledge, M. L., \& Warden, M. A. (2000). Evolutionary theory, the nature of science \& high school biology teachers: Critical relationships. The American Biology Teacher, 62(1), 23-31.

Sadler, T. D. (2011). Situating socio-scientific issues in classrooms as a means of achieving goals of science education. In T. D. Sadler (Ed.), Socio-scientific issues in the classroom. Contemporary trends and issues in science education, (vol. 39, pp. 1-9). Dordrecht: Springer.

Sadler, T. D., Chambers, F. W., \& Zeidler, D. L. (2004). Student conceptualizations of the nature of science in response to a socioscientific issue. International Journal of Science Education, 26(4), 387-409.

Sadler, T. D., Foulk, J. A., \& Friedrichsen, P. J. (2017). Evolution of a model for socio-scientific issue teaching and learning. International Journal of Education in Mathematics, Science and Technology, 5(2), 75-87.

Sadler, T. D., \& Fowler, S. R. (2006). A threshold model of content knowledge transfer for socioscientific argumentation. Science Education, 90(6), 986-1004.

Saunders, K. J., \& Rennie, L. J. (2013). A pedagogical model for ethical inquiry into socioscientific issues in science. Research in Science Education, 43(1), 253-274.

Scharmann, L. C., \& Harris Jr., W. M. (1992). Teaching evolution: Understanding and applying the nature of science. Journal of Research in Science Teaching, 29(4), 375-388.

Schmidt, W. H., Wang, H. C., \& McKnight, C. C. (2005). Curriculum coherence: An examination of US mathematics and science content standards from an international perspective. Journal of Curriculum Studies, 37(5), 525-559.

Schrein, C. M. (2014). Where did you come from? Where will you go? Human evolutionary biology education and American students' academic interests and achievements, professional goals, and socioscientific decision-making. (Doctoral dissertation). Arizona State University: Tempe.

Schwarz, C. V., Gunckel, K. L., Smith, E. L., Covitt, B. A., Bae, M., Enfield, M., \& Tsurusaki, B. K. (2008). Helping elementary preservice teachers learn to use curriculum materials for effective science teaching. Science Education, 92(2), $345-377$.

Shankar, G., \& Skoog, G. D. (1993). Emphasis given evolution and creationism by Texas high school biology teachers. Science Education, 77(2), 221-223.

Shenton, A. K. (2004). Strategies for ensuring trustworthiness in qualitative research projects. Education for Information, 22(2), 63-75.

Short, S. D., \& Hawley, P. H. (2015). The effects of evolution education: Examining attitudes toward and knowledge of evolution in college courses. Evolutionary Psychology, 13(1), 67-88.

Shtulman, A. (2006). Qualitative differences between naïve and scientific theories of evolution. Cognitive Psychology, 52(2), 170-194. 
Shulman, L. (1987). Knowledge and teaching: Foundations of the new reform. Harvard Educational Review, 57(1), 1-23.

Sickel, A. J., Banilower, E., Carlson, J., \& Van Driel, J. (2015). Examining PCK research in the context of current policy initiatives. In Re-examining pedagogical content knowledge in science education, (pp. 199-213).

Skoog, G. (1979). Topic of evolution in secondary school biology textbooks: 19001977. Science Education, 63(5), 621-640.

Skoog, G. (1984). The coverage of evolution in high school biology textbooks published in the 1980s. Science Education, 68(2), 117-128.

Skoog, G. (2005). The coverage of human evolution in high school biology textbooks in the 20th century and in current state science standards. Science \& Education, 14(3-5), 395-422.

Skoog, G., \& Bilica, K. (2002). The emphasis given to evolution in state science standards: A lever for change in evolution education? Science Education, 86(4), 445-462.

Smith, M. U. (2010). Current status of research in teaching and learning evolution: II. Pedagogical issues. Science \& Education, 19(6-8), 539-571.

Smithsonian Institution. (2019). Human evolution evidence. Retrieved from http:// humanorigins.si.edu/evidence

Smithsonian Institution. (n.d.). For Educators. Retrieved August 24, 2020, from https://www.si.edu/educators

Smithsonian National Museum of Natural History. (2018). Science, religion evolution and creationism: Primer. Retrieved from http://humanorigins.si.edu/ about/broader-social-impacts-committee/science-religion-evolution-andcreationism-primer

Spillane, J. P. (2002). Local theories of teacher change: The pedagogy of district policies and programs. Teachers College Record, 104(3), 377-420.

Summers, R., \& Abd-El-Khalick, F. (2019). Examining the representations of NOS ineducational resources. Science \& Education, 28(3-5), 269-289.

Swanson, C. B. (2005). Evolution in state science education standards. Retrieved from http://www.edweek.org/media/epe_evolution1105.pdf

Taber, K. S. (2017). Knowledge, beliefs and pedagogy: How the nature of science should inform the aims of science education (and not just when teaching evolution). Cultural Studies of Science Education, 12(1), 81-91.

Tinsley, H. E., \& Brown, S. D. (2000). Interrater reliability and agreement. In E. A Howard, \& S. D. Brown (Eds.), Handbook of applied multivariate statistics and mathematical modeling, (pp. 95-124). Cambridge: Academic

Tshuma, T., \& Sanders, M. (2015). Textbooks as a possible influence on unscientific ideas about evolution. Journal of Biological Education, 49(4), 354-369.

Watts, E., Levit, G. S., \& Hoßfeld, U. (2016). Science standards: The foundation of evolution education in the United States. Perspectives in Science, 10, 59-65.

Weiss, I. R., Pasley, J. D., Smith, P. S., Banilower, E. R., \& Heck, D. J. (2003). Looking inside the classroom. Chapel Hill: Horizon Research Inc.

Wilde, S., Timpson, A., Kirsanow, K., Kaiser, E., Kayser, M., Unterländer, M., Burger, J. (2014). Direct evidence for positive selection of skin, hair, and eye pigmentation in Europeans during the last 5,000 y. Proceedings of the National Academy of Sciences, 111(13), 4832-4837.

Wongsri, P., \& Nuangchalerm, P. (2010). Learning outcomes between socioscientific issues-based learning and conventional learning activities. Online Submission, 6(2), 240-243.

Zeidler, D. L., Herman, B. C., \& Sadler, T. D. (2019). New directions in socioscientific issues research. Disciplinary and Interdisciplinary Science Education Research, 1(11), 1-9. https://doi.org/10.1186/s43031-019-0008-7.

Zeidler, D. L., \& Nichols, B. H. (2009). Socioscientific issues: Theory and practice. Journal of Elementary Science Education, 21(2), 49-58.

Zeidler, D. L., Sadler, T. D., Simmons, M. L., \& Howes, E. V. (2005). Beyond STS: A research-based framework for socioscientific issues education. Science Education, 89(3), 357-377.

\section{Publisher's Note}

Springer Nature remains neutral with regard to jurisdictional claims in published maps and institutional affiliations.

\section{Submit your manuscript to a SpringerOpen ${ }^{\circ}$ journal and benefit from:}

- Convenient online submission

- Rigorous peer review

- Open access: articles freely available online

- High visibility within the field

- Retaining the copyright to your article

Submit your next manuscript at $\boldsymbol{\nabla}$ springeropen.com 